\title{
Assessment of indoor air quality and heat stress exposure in an automotive assembly plant
}

\author{
Aziah Daud1, Edimansyah Abdin2*, Azwan Aziz1, \\ Lin Naing 3 and Rusli Nordin 4 \\ 1. Division of Occupational Medicine, Department of Community Medicine, School of \\ Medical Sciences, Health Campus, Universiti Sains Malaysia, Kelantan, \\ 16150 Malaysia \\ 2. (Correspondence author) Institute of Mental Health, Buangkok Green Medical Park, \\ 10 Buangkok View, \\ Singapore 539747 \\ 3. Institute of Medicine, National University of Brunei Darussalam, Jalan Tungku Link, \\ Gadong BE 1410, Brunei Darussalam \\ 4. Clinical School Johor Bahru, Tan Sri Jeffrey Cheah School of Medicine and Health \\ Sciences, Monash University, Johor Bahru, Johor, 80100 Malaysia
}

\section{Introduction}

Indoor air quality and heat exposure have become an important occupational health and safety concern in the workplace. The indoor environment is important not only because of the amount of time spent inside buildings but because there are indoor sources of pollution, including, heating and cooking appliances, open fires, building and insulation materials, furniture, fabrics and furnishings, glues, cleaning products, other consumer products, and various biological sources, such as house dust mites, fungi, and bacteria. There is also the inflow of polluted outdoor air through windows, evaporation of substances from water, and, in some locations, infiltration of radon and other gases into the building from the underlying soil and bedrock (Harrison, 2002).

Indoor air quality is the result of an intricate series of interactions involving many indoor and outdoor ventilation, microbiological, toxicological, and physical systems (Jones, 2002). Exposure to indoor toxicants can potentially lead to a variety of adverse health outcomes (Bascom et al., 1995). The likelihood that an individual will become ill from the presence of a contaminant depends upon factors such as the individual's sensitivity to that contaminant, the contaminant concentration, the current state of their psychological and physical health and the duration and frequency of exposure (Seltzer, 1997). Indoor air pollutants have the potential to cause transient morbidity, disability, disease, and even death in extreme cases 
(Berglund et al., 1992). Recent research into these health outcomes has involved human, animal, and in vitro studies (Maroni et al., 1995).

Heat stress is readily associated with high environmental temperatures and humidity. Many work environments expose workers to extremely hot and humid conditions. Heat-related illness is a problem for many types of workers: metal smelters, outdoor construction and law enforcement workers, plastics manufacturing workers, landscaping and recreation maintenance personnel, staff in warehouses without air conditioning, cooks and kitchen workers, and athletes. A number of human factors contribute to a worker's susceptibility to heat stress, such as medical conditions, increasing age, overall level of fitness, presence of other metabolically stressful illnesses, the use of certain medications, dehydration, alcohol intake, and individual ability to acclimatize to extreme temperatures. Environmental factors that can contribute to heat stress besides high ambient temperature are low convection currents, high humidity, low evaporative loss, and high insulation levels around the body (Ramphal, 2000).

Heat is a form of energy. It can be generated either endogenous or exogenous process (Simon, 1994). Heat stress from safety and health point of view is physical hazards which can cause health effects direct or indirect into certain industrial workers. Workers are potentially exposed to heat will facing heat stress symptoms if they are not protected. Environmental factors such as ambient temperature, relative humidity, radiant heat, conduction and air velocity plays a major roles contribute to heat stress problems (OSHA, 1999).

\section{Important of the Study}

The automotive assembly plant in the automotive industry is well known to be a stressful working environment. The automotive assembly plant is usually configured as three successive shops in which the body is constructed, painted, and then assembled together with all component parts into a finished vehicle (Figure 1). Kvarnström (1997) reported that an automotive assembly-line work is often perform in a workplace environment with physical problems, such as noise, vibrations and dangerous machines that can be important stress factors.

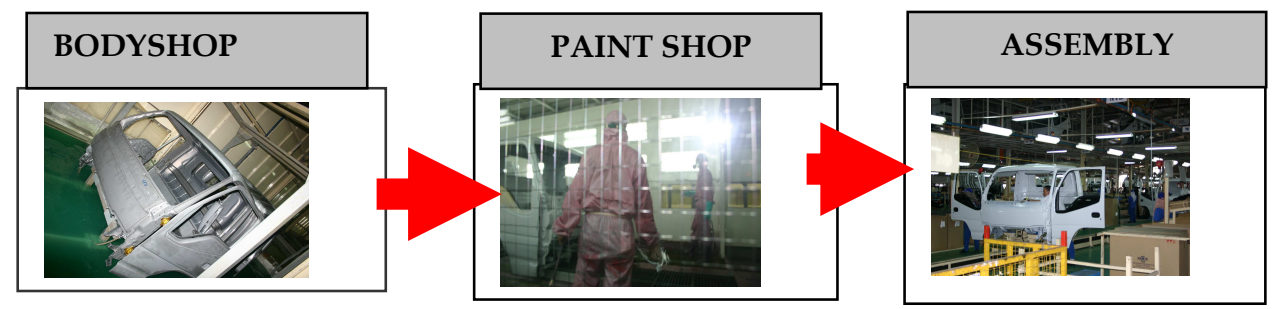

Fig. 1. Three stages of car manufacturing process

The automotive assembly plant is one of the main contributors to different types of pollutants. For instance, waste from plastics, aluminum, cooper, rags, sandpapers, solvents 
and paints can be generated. In particular, automotive painting processes generates, among other issues, VOC emissions as paint solvents. Automotive painting and coating products are formulated by using resins, pigments, volatile organic solvents, and chemical additives. Unfortunately, the automotive coatings process ranks at the top of the emission volume hierarchy. For this reason, knowing the pollution sources and their characteristics in this sector is important for a proper prevention. Several initiatives have been developed worldwide to promote occupational health and safety, and environmental protection through regulations, code of practices, and guidelines for prevention (Esquer et al, 2009).

In an automotive assembly plant, exposure to indoor air pollutants and heat are probably one of the most dangerous health hazards for the workers. Workers involved in auto body repair are potentially exposed to a multitude of air contaminants. During structural repair, activities such as sanding, grinding, and welding generate aerosols that are released into the worker's breathing zone. If the surface of the car being repaired contains toxic metals, such as lead, cadmium, or chromium, exposure to these metals, is possible. Workers who paint cars can be exposed to organic solvents, hardeners that may contain isocyanate resins and pigments that may contain toxic components (NIOSH, 1993).

In Malaysia, IAQ has been recognized by the Department of Occupational Safety and Health (DOSH) as a critical issue (DOSH, 2006). In order to ensure all workers are protected from indoor air pollutants, the department has set forth a code of practice entitled "Code of Practice on Indoor Quality" (DOSH, 2005). This code of practice is applied to all industries in Malaysia including the automotive industry. One of the aims of the code was to establish a set of maximum exposure limits for common indoor air contaminants, such as carbon monoxide, carbon dioxide and respirable particulates (DOSH, 2005).

In Malaysia, although indoor air pollutants and heat exposure pose a risk to the worker's health, few studies have been conducted in this industry. This is a serious omission because the automotive industry is a key player in the manufacturing sector, a high income generating industry and a government-linked company in Malaysia. In 2004, Malaysia was the largest producer of passenger cars in the Association of Southeast Asian Nations (ASEAN), accounting for $24.4 \%$ of the total ASEAN motor vehicle production. For commercial vehicles, Malaysia was the third largest producer, accounting for $11.0 \%$ of the total ASEAN production (Prime Minister's Department, 2005). Therefore, the aim of this study was to determine the concentration of five common IAQ contaminants [carbon dioxide (CO2), carbon monoxide (CO), respirable particulate matter (PM10), temperature and relative humidity (RH)] and pattern of heat stress in the paint shop and body shop sections of an automotive assembly plant in Malaysia.

\section{Materials and Methods}

\subsection{Study design}

A cross-sectional study of the two sections (paint and body shops) was conducted in 2005 at an automotive industry plant located in Rawang, Selangor. During the assessment, workers in paint shop section who were involved in study were worked in body preparation of car before sending the body car into the primer booth (drying oven). They started their work 
from 8.00 a.m to 6.00 p.m. They had their morning break at 10.30 a.m to 10.45 a.m, lunch break at 1.00 p.m to 2.00 p.m and evening break at 4.30 p.m to 4.14 p.m. Workers in body shop section worked as welder (welding a car components using electronic spot gun welder). Their work times were almost the same as workers in paint shop section.

\subsection{Indoor air quality (IAQ) monitoring}

After walk-through surveys of the sites, data collection of IAQ was done using directreading instruments [the Q-TRAK ${ }^{\mathrm{TM}}$ Plus IAQ Monitor (TSI Inc, 2003a) and the DUSTTRAKTM aerosol monitor (TSI Inc, 2003b)] during an eight hour work shift from 9:30 AM to 5:30 PM during painting and sanding operations. The instruments were located in both sections (body and paint sections). The Q-TRAK ${ }^{\mathrm{TM}}$ Plus IAQ Monitor (TSI Inc, 2003a) was used to record the $\mathrm{CO}, \mathrm{CO} 2$, temperature and $\mathrm{RH}$ levels using a survey mode at one second intervals. This mode was used to display the real-time readings of all parameters simultaneously. Before sampling, the Q-TRAK ${ }^{\mathrm{TM}}$ Plus IAQ Monitor was calibrated for CO2 and $\mathrm{CO}$ by running a span gas with a known concentration and a zero gas through the monitor by the local TSI distributor. The span gas concentrations for $\mathrm{CO} 2$ and $\mathrm{CO}$ were $1,000 \mathrm{ppm}$ and $35 \mathrm{ppm}$, respectively. If measurements were not within specifications, the instrument was recalibrated. The Q-TRAK ${ }^{\mathrm{TM}}$ Plus IAQ Monitor (TSI Inc, 2003a) uses a nondispersive infrared sensor for measuring $\mathrm{CO} 2$ concentration, an electrochemical sensor for measuring $\mathrm{CO}$ concentration, a thermistor for measuring temperature, and a thin-film capacitive element for measuring relative humidity (Ramachandran et al, 2002). A DUSTTRAK тм aerosol monitor (TSI Inc, 2003b) was used to measure PM10. The DUSTTRAK TM aerosol monitor measures PM10 at one minute intervals at a flow-rate of 1.7 $1 /$ minute. Before sampling, pre- and post-zero checks of the DUST-TRAK aerosol monitor were carried out. The DUST-TRAK aerosol monitor is an optical instrument that detects particles in the air matrix by optical scattering, using the optical diameter instead of the aerodynamic diameter (Guo et al, 2004). The data was analyzed using TrakProTM v3.41 software.

\subsection{Heat stress monitoring}

In this study, heat stress monitor (Model: QUESTempo34 Thermal Environment Monitor, Quest Technologies, USA) was used to measure the heat stress data. This data logging area heat stress monitor measures four parameter: ambient or dry temperature (DB), natural wet bulb temperature (WB), globe temperature (GB), and relative humidity $(\mathrm{RH})$. The details of definition and calculation of WBGT were published elsewhere (NIOSH 1986). This study was used WBGT indoor (WBGT $\mathrm{T}_{\text {indoor}}$ ) index as results. Both of sections were in enclosure setting. Heat stress monitor was placed at the nearest position to the workers without interrupted their movements and job tasking. This machine was set at 1.1 meter height in stand position and supported by the standard photographic tripod. Tripod mounting is recommended to get the unit away from anything that might block radiant heat or airflow. Wet bulb reservoir is filled with distilled water. After adding water and placing the unit, all parameter were stabilizing in surrounding area for 10 minutes. The machine was calibrated before and after the measurements using calibration sensor module. After all procedure done, measurement started and the machine recorded automatically in data logger. Heat measurements took eight hours with interval one hour recorded all four parameter. All 
setting was followed NIOSH (1986) standards. Eight hours exposure is a standard where calculation based time-weighted average WBGT (TWA-WBGT $\mathrm{T}_{\text {indoor }}$ ) with the equation below:

$$
\frac{\mathbf{W B G T}_{1} \times \mathbf{t}_{1}+\mathbf{W B G T}_{2} \times \mathbf{t}_{2}+\ldots \ldots \ldots+\mathbf{W B G T}_{\mathrm{n}} \times \mathbf{t}_{\mathrm{n}}}{\mathbf{t}_{1}+\mathbf{t}_{2}+\ldots \ldots \ldots+\mathbf{t}_{\mathrm{n}}}
$$

where:

$\mathrm{WBGT}_{1} \times \mathrm{t}_{1}+\mathrm{WBGT}_{2} \times \mathrm{t}_{2}+\ldots \ldots .+\mathrm{WBGT}_{\mathrm{n}} \times \mathrm{t}_{\mathrm{n}}=\mathrm{WBGT}$ values per hour $t_{1}+t_{2}+\ldots .+t_{n}=$ duration of exposure per hour

Heat monitoring started at 10.00 a.m and end-up at 5.00 p.m. The results of heat measurements were printed directly from the machine and all parameter were analyzed. The workplace which had WBGT indoor more than $28 \mathrm{oC}\left(>28{ }^{\circ} \mathrm{C}\right)$ was considered hot and $\mathrm{WBGT}_{\text {indoor }}$ less than $27.9^{\circ} \mathrm{C}\left(\leq 27.9^{\circ} \mathrm{C}\right)$ were considered normal (Granadillos, 1998).

\subsection{Workload and work-rest regime evaluation}

As described earlier, WBGT index can predict the severity of heat exposure. It is also can showed suggested allowable work-rest regime for given workload. The American Conference of Governmental Industrial Hygienists (ACGIH, U.S) published a standard time-limited values (TLVs) for WBGT indices (ACGIH, 1992).

For the purpose of the study, workers who worked in paint shop section were considered in acclimatized workers and workers in body shop section were considered in unacclimatized workers. Acclimatized workers means the workers were exposure gradually to the hot environment for 14 days or more (NIOSH, 1986) where else unacclimatized were verse versa . Over all, workers in the paint shop and body shop sections were in moderate workload and worked in $75 \%$ work / $25 \%$ rest in work-rest regime scales according to ACGIH standards (ACGIH, 2001). Below is the table of Screening Criteria for Heat Stress Exposure by ACGIH.

\begin{tabular}{lcccc}
\hline \hline Work demand & Light & Moderate & Heavy & Very heavy \\
\hline $100 \%$ work & $25.9{ }^{\circ} \mathrm{C}$ & $27.5{ }^{\circ} \mathrm{C}$ & $26.0^{\circ} \mathrm{C}$ & \\
$75 \%$ work & $30.5{ }^{\circ} \mathrm{C}$ & $28.5{ }^{\circ} \mathrm{C}$ & $27.5{ }^{\circ} \mathrm{C}$ & \\
$25 \%$ rest & & & & \\
$50 \%$ work & $31.5{ }^{\circ} \mathrm{C}$ & $29.5{ }^{\circ} \mathrm{C}$ & $28.5{ }^{\circ} \mathrm{C}$ & $27.5{ }^{\circ} \mathrm{C}$ \\
$50 \%$ rest & & & & \\
$25 \%$ work & $32.5{ }^{\circ} \mathrm{C}$ & $31.0{ }^{\circ} \mathrm{C}$ & $30.0{ }^{\circ} \mathrm{C}$ & $29.5{ }^{\circ} \mathrm{C}$ \\
$75 \%$ rest & & & & \\
\hline \hline
\end{tabular}

Table 1. Screening criteria for heat stress exposure of acclimatized person 


\begin{tabular}{lcccc}
\hline \hline Work demand & Light & Moderate & Heavy & Very heavy \\
\hline $\begin{array}{l}100 \% \text { work } \\
75 \% \text { work }\end{array}$ & $27.5{ }^{\circ} \mathrm{C}$ & $25.0^{\circ} \mathrm{C}$ & $22.5^{\circ} \mathrm{C}$ & \\
$25 \%$ rest & $29.0^{\circ} \mathrm{C}$ & $26.5{ }^{\circ} \mathrm{C}$ & $24.5^{\circ} \mathrm{C}$ & \\
$\begin{array}{l}50 \% \text { work } \\
50 \% \text { rest }\end{array}$ & $30.0{ }^{\circ} \mathrm{C}$ & $28.0{ }^{\circ} \mathrm{C}$ & $26.5{ }^{\circ} \mathrm{C}$ & $25.0{ }^{\circ} \mathrm{C}$ \\
$\begin{array}{l}25 \% \text { work } \\
75 \% \text { rest }\end{array}$ & $31.0{ }^{\circ} \mathrm{C}$ & $29.0{ }^{\circ} \mathrm{C}$ & $28.0{ }^{\circ} \mathrm{C}$ & $26.5{ }^{\circ} \mathrm{C}$ \\
\hline \hline
\end{tabular}

Table 2. Screening criteria for heat stress exposure of unacclimatized person

\section{Results}

\begin{tabular}{lllllllllll}
\hline \multirow{2}{*}{ Parameters } & $\begin{array}{l}\text { DOSH } \\
\text { Standard* } \\
\text { in 8-TWA }\end{array}$ & \multicolumn{3}{c}{ Paint Shop Section } & \multicolumn{5}{c}{ Body Shop Section } \\
\cline { 3 - 10 } & & Mean & SD & Min & Max & Mean & SD & Min & Max \\
\hline $\begin{array}{l}\text { Temperature } \\
\left({ }^{\circ} \mathrm{C}\right)\end{array}$ & $20-26$ & 32.5 & 1.2 & 29.3 & 33.9 & 29.7 & 1.0 & 27.8 & 30.8 \\
$\mathrm{RH}(\%)$ & $40-60$ & 65.5 & 2.3 & 62.6 & 71.3 & 72.9 & 2.4 & 69.8 & 78.4 \\
$\mathrm{CO}$ ppm & 10 & 1.1 & 0.2 & 0.5 & 1.8 & 2.0 & 0.4 & 1.4 & 3.1 \\
$\mathrm{CO}$ & $\mathrm{C} 1000$ & 252.8 & 30.7 & 204 & 360 & 252.5 & 28.3 & 204 & 339 \\
$\mathrm{PM}_{10} \mathrm{mg} / \mathrm{m}^{3}$ & 0.15 & 0.4 & 0.1 & 0.2 & 1.6 & 0.4 & 0.1 & 0.2 & 2.4
\end{tabular}

Table 3. Descriptive summary of selected IAQ parameters in the paint shop section and body shop section

Note: $\mathrm{C}$ is the ceiling limit, $\mathrm{mg} / \mathrm{m}^{3}$ is milligrams per cubic meter of air at $25^{\circ}$ Celsius and one atmosphere pressure, ppm is parts of vapors or gas per million parts of contaminated air by volume, 8-TWA is time-weighted average for up to 8 hours/day

* (DOSH, 1996) and (DOSH, 2005)

\subsection{IAQ Parameters}

\subsubsection{Temperature and $\mathrm{RH}$}

Fig 2 shows the average temperature and $\mathrm{RH}$ obtained in the paint and body shop sections. The average temperature in the paint shop section was $32.5 \pm 1.2^{\circ} \mathrm{C}\left(29.7-33.9^{\circ} \mathrm{C}\right.$ and, in the body shop section the average temperature was $29.7 \pm 1.0^{\circ} \mathrm{C}\left(27.8-30.8^{\circ} \mathrm{C}\right)$. The relative humidity in the body shop section ranged from 69.8 to $78.4 \%$ with an average of $72.9 \pm 2.4 \%$. The $\mathrm{RH}$ in the paint shop section was $65.5 \pm 2.3 \%$ (62.6-71.3), higher than that in the body shop. The temperature and $\mathrm{RH}$ of both sections exceeded those recommended by the DOSH (Table 3). 


\subsubsection{CO}

Fig 3 shows the concentrations of $\mathrm{CO}$ in the paint and body shop sections. The results show that the concentration of $\mathrm{CO}$ in the body shop ranged from 1.4 to 3.1 with an average of 2.0 $\pm 0.4 \mathrm{ppm}$. In the paint shop, the concentration of $\mathrm{CO}$ ranged from 0.5 to $1.8 \mathrm{ppm}$ with an average of $1.1 \pm 0.2 \mathrm{ppm}$. The average concentration of $\mathrm{CO}$ in the body shop was higher than that in the paint shop. However, the concentrations of $\mathrm{CO}$ in both sections were within DOSH standard limits (Table 3).

\subsubsection{CO2}

Fig 4 shows the concentrations of $\mathrm{CO} 2$ in the paint and body shop sections. The results show the average concentration of $\mathrm{CO} 2$ in the paint shop was $252.8 \pm 30.7 \mathrm{ppm}$, which was slightly higher than in the body shop $(252.5 \pm 28.3 \mathrm{ppm})$. The concentrations of $\mathrm{CO} 2$ in the paint and body shop sections were 204-360 and 204-339 ppm, respectively. These concentrations were within the DOSH standard limits (Table 3).

\subsubsection{PM10}

Fig 5 shows the concentrations of PM10 in the paint and body shop sections. The PM10 concentration in the paint shop section ranged from 0.2 to $1.6 \mathrm{ppm}$, with an average of $0.4 \pm$ $0.1 \mathrm{ppm}$, in the body shop section it was $0.4 \pm 0.1 \mathrm{ppm}(0.2-2.4 \mathrm{ppm})$. The average PM10 in both sections exceeded the DOSH standard limits (Table 3 ).
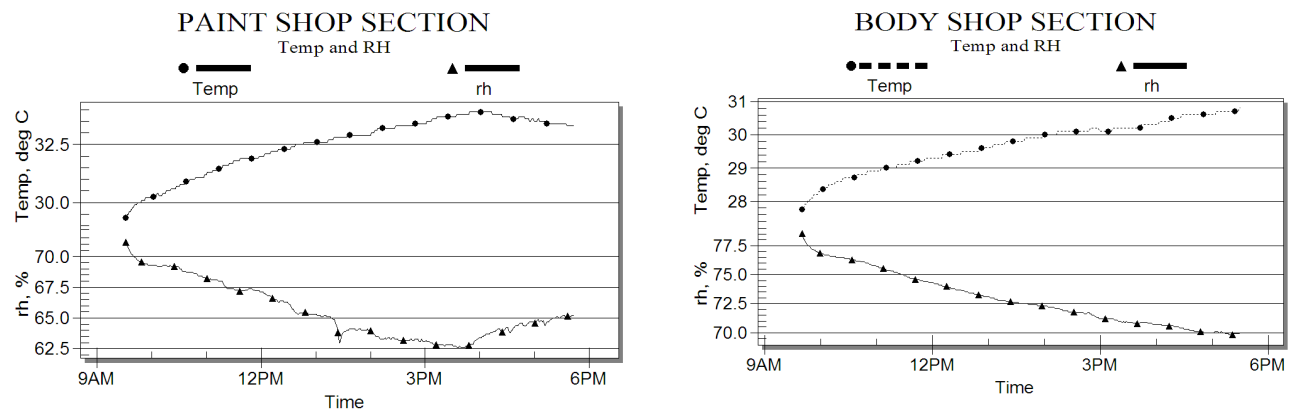

Fig. 2. Temperature and $\mathrm{RH}$ in the paint shop section (a) and body shop section (b)
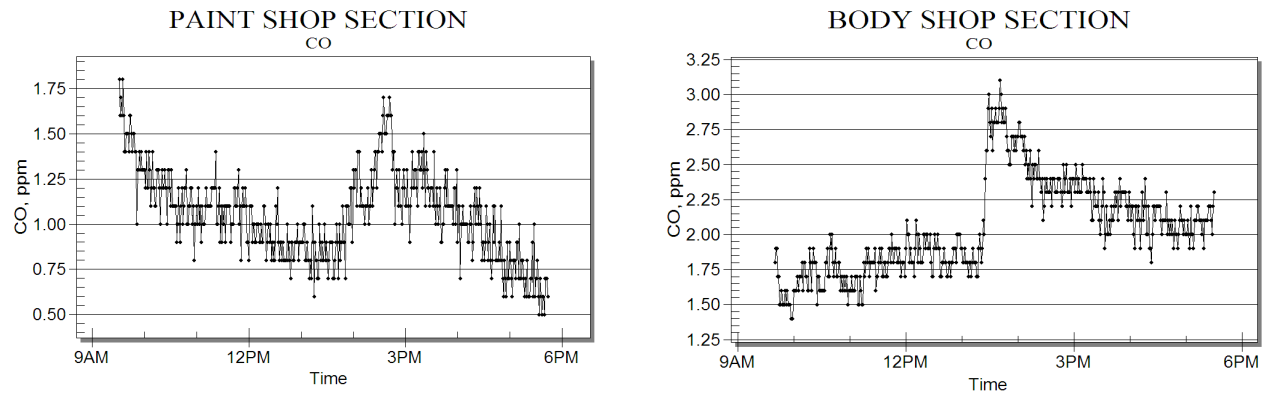

Fig. 3. The concentration of CO in the paint shop (a) and body shop section (b) 

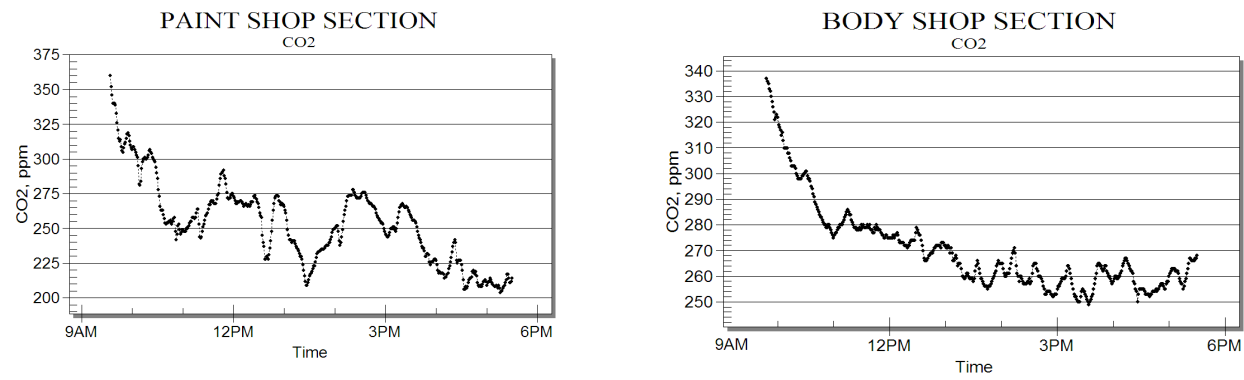

Fig. 4. Concentrations of $\mathrm{CO}_{2}$ in the paint shop (a) and body shop section (b)
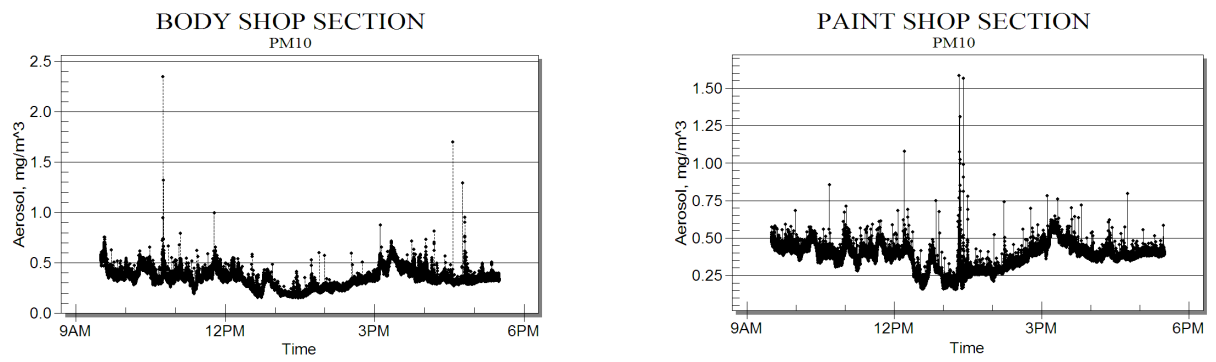

Fig. 5. Concentrations of PM10 in the paint shop (a) and body shop section (b)

\subsection{Heat stress}

All result of paint shop and body shop section were showed in Table 4. As over all, the study showed heat parameters in paint shop section (DB, WB and GB) were higher than heat parameter in body shop section. The TWA-WBGT indoor $_{\text {of }}$ paint shop was higher (28.3

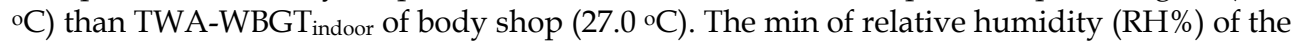
paint shop was $48 \mathrm{RH} \%$ lower than $\mathrm{RH} \%$ in body shop (55 RH\%).

\begin{tabular}{lcc}
\hline \hline Heat parameters (min) & \multicolumn{2}{c}{ Section } \\
\cline { 2 - 3 } & Paint shop & Body shop \\
\hline $\begin{array}{l}\text { Dry temperature (DB) } \\
\left(\text { in }{ }^{\circ} \text { C) }\right.\end{array}$ & 34.3 & 32.2 \\
$\begin{array}{l}\text { Wet bulb temperature (WB) } \\
\left(\text { in }{ }^{\circ} \text { ) }\right.\end{array}$ & 25.5 & 24.8 \\
$\begin{array}{l}\text { Globe temperature (GB) } \\
\text { (in }{ }^{\circ} \text { C) }\end{array}$ & 34.8 & 32.2 \\
$\begin{array}{l}\text { TWA-WBGT } \\
\text { (in }{ }^{\circ} \text { C) }\end{array}$ & 28.3 & 27.0 \\
Relative humidity (RH\%) & 48 & 55 \\
\hline \hline
\end{tabular}

Table 3. Comparison of heat parameters in paint shop and body shop

Heat parameters (TWA-WBGT ${ }_{\text {indoor, }}$ DB, WB and GB) in paint shop were increased higher than heat parameters in body shop by time of measuring. By the way, both of the section 
relatively showed all heat parameters were gradually increased by time (Figure 6). Meanwhile, $\mathrm{RH} \%$ in paint shop was gradually decreased lower than $\mathrm{RH} \%$ in body shop from start to end measuring (Figure 7). From the study, paint shop was considered "hot area" $\left(>28^{\circ} \mathrm{C}\right)$ and body shop was considered "normal area" $\left(\leq 27.9^{\circ} \mathrm{C}\right)$.

In paint shop section, workers were worked in moderate workload and worked in $75 \%$

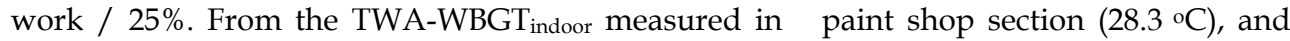
compared with screening criteria for heat exposure in Table 3 (75\% work / 25\%: moderate: acclimatized: $28.5^{\circ} \mathrm{C}$ ), workers were not exposed to heat stress. This condition was similar in workers in body shop when TWA-WBGT indoor measured was $27.0{ }^{\circ} \mathrm{C}$ (75\% work / 25\%: moderate: unacclimatized: $26.5^{\circ} \mathrm{C}$ ).
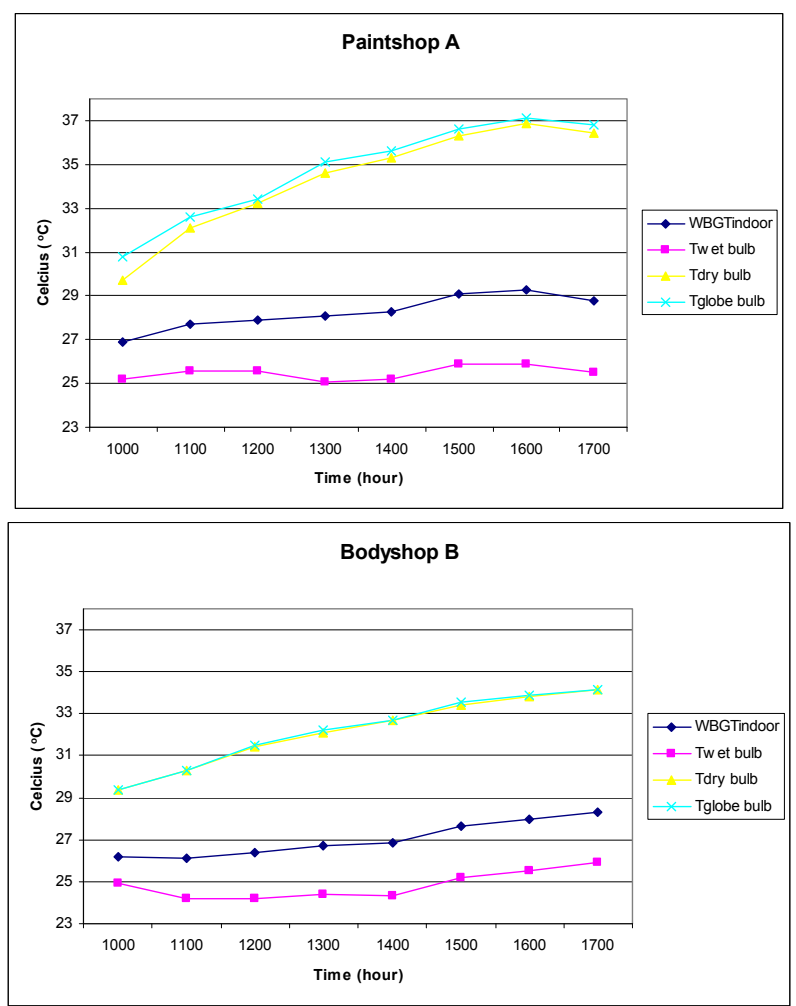

Fig. 6. The comparison heat parameters pattern in paint shop and body shop in 8 hours measuring time 


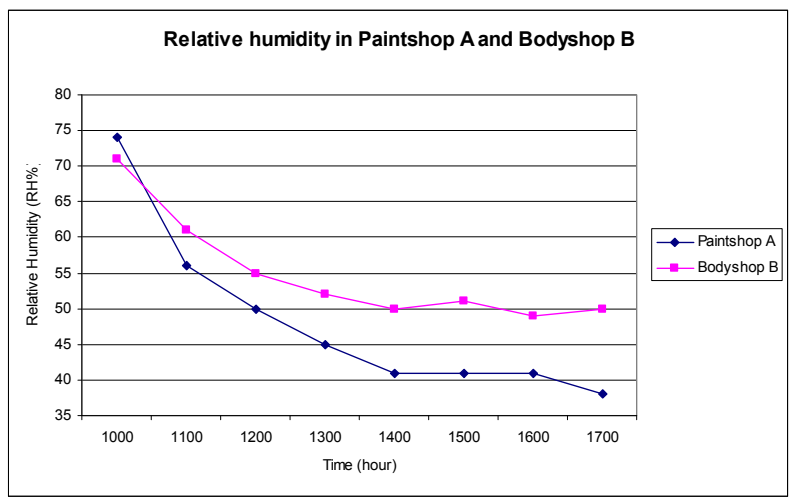

Fig. 7. The comparison relative humidity ( $\mathrm{RH} \%)$ pattern in paint shop and body shop in 8 hours measuring time

\section{Discussion and Conclusion}

The present study was aim to determine the concentration of five common IAQ contaminants [carbon dioxide (CO2), carbon monoxide $(\mathrm{CO})$, respirable particulate matter (PM10), temperature and relative humidity $(\mathrm{RH})]$ and pattern of heat stress in the paint shop and body shop sections of an automotive assembly plant in Malaysia. We found that the temperature and $\mathrm{RH}$ in both sections exceeded the DOSH standard limits. The recommended optimum comfort range for $\mathrm{RH}$ according to $\mathrm{DOSH}$ is $40 \%$ to $60 \%$. Low humidity can cause dryness of the eyes, nose and throat and may also increase the frequency of static electricity shocks. The relative humidity in the body shop ranged from 69.8 to $78.4 \%$ with an average of $72.9 \pm 2.4 \%$. High humidity, above $80 \%$, can be associated with fatigue and "stuffiness" (DOSH, 1996).

We suggest the air-conditioning in this area should be monitored regularly. Humidity can result in the growth of mould and dust mites within the area if allowed to become too high. Rapid growth occurs when levels of humidity are above $60 \%$, with a negative effect on respiratory illnesses such as asthma. If the level of humidity becomes too low, below $30 \%$, this too can have adverse effects, with some people developing sore throats due to dryness of the air (DOSH, 1996). In this study, the concentration of $\mathrm{CO}$ and $\mathrm{CO} 2$ were within the DOSH standard limits.

Our study found that the mean PM10 levels in both sections exceeded the DOSH recommendations at $0.15 \mathrm{mg} / \mathrm{m} 3$. Inadequate ventilation of the sanders occurred during sanding in the body shop which probably contributed to increased levels of PM10 in the body shop. In the paint shop the high concentration of PM10 could be due to various organic solvents and paint overspraying. Thus, respirators need to be used properly to prevent worker exposure to air contaminants in the paint shop. Exhaust ventilation and process isolation are commonly used controls for PM10 reduction. In conclusion, the workers in the paint and body shop sections were exposed to high concentrations of $\mathrm{RH}$, temperature and PM10. Therefore, IAQ management programs, engineering controls, 
training and education should be conducted in these sections to minimize IAQ problem exposure.

In terms of heat stress monitoring, we found the heat environment in paint shop section was hot compared with body shop section. The study carried by Aziz (2003) in automobile found that, the TWA-WBGT $T_{\text {indoor }}$ in paint shop was $29.2{ }^{\circ} \mathrm{C}$ and body shop was $24.7{ }^{\circ} \mathrm{C}$. This condition happens because of the work process itself. In paint shop as a process, the work involved drying methods which painted car will have to dry in the oven booth before goes to assembly shop. The building itself was enclosed, so that the heat generated by oven booth will accumulated gradually through section. As a result, workers who worked nearest the heat source were potentially exposed to the hot environments. Environmental factors such as ambient temperature, relative humidity, radiant heat, conduction, air velocity and work process can cause heat stress problems to the workers in hot workplaces (OSHA, 1999).

Paint shop was consider in hot (WBGT $>28^{\circ} \mathrm{C}$ ) compared with body shop (WBGT $\leq 27.9^{\circ} \mathrm{C}$ ). Its mean, the workers who worked in paint shop were potentially exposed to heat stress problems compared workers in body shop (Ramsey, 1999). A paint shop was considered hot-dry section $(\mathrm{RH} \%>50)$ and body shop was considered hot-warm (\% RH 50-70). A study by Aziz (2003) showed workers in paint shop section were pruned to have heat stress problems in hot-dry condition. The workers in body shop can also have heat stress problems in hot-warm condition. If there is not air movement, the rates of sweat evaporation on skin decreased if humidity increased. So, hot-warm can be stressful than hot-dry condition (BOHS, 1990). According to standard of screening criteria for heat stress exposure table 1 and table 2 by AGCIH, workers in both sections can worked in their workrest regime schedule without having heat stress problems. Work-rest regime is very important in preventing heat stress in hot environment (OSHA, 1999). If the workers worked in very hot environment with unsuitable work-rest regime, heat stress may high to them.

Acclimatization program can increase the capability of heat tolerance to the workers who worked in hot condition (Graveling et al, 1998). Acclimatized workers can prevent the heat stress problems because their physiological system will responds immediately when they were exposed to hot environment. Acclimatization program in 7-14 days can improve the workers capability to the hot environment (Wildeboor and Camp, 1993). Therefore this program should be implemented in hot area like paint shop section.

Heat stress monitoring in potential hot workplace should be monitor regularly. Thermal indices like WBGT is the easiest way to predict the heat stress problem to the workers. Although, this index is not giving more information on physiological changes in workers who worked in hot environment, this is the effective way for early detection. The most important system to tackle heat stress problems is heat stress management program. Beside, the engineering control in workplace, training and education in heat stress management to the workers can create the awareness among them when working in hot situation. Then, heat stress problem can be reduced and safety and health of the workers will be protected. 


\section{References}

ACGIH. (1992). A manual of recommended practice, American Conference of Govermental Industrial Hygienists

ACGIH. (2001). American Conference of Governmental Industrial Hygienists - Threshold Limits Values and Biological Exposure Indices for 2001, American Conference of Governmental Industrial Hygienists

Bascom, R. Kesavanathan, J. Swift, D.L. (1995). Human susceptibility to indoor contaminants. Occupational Medicine 10 (1), 119-132.

BOHS (1990). The Thermal Environment. Technical Guide \# 8, British Occupational Hygiene Society

Berglund, B. Brunekreef, B. Knoppel, H. Lindvall, T. Maroni, M. L. Skov, P. (1992). Effects of indoor air pollution on human health. Indoor Air 2(1), 2-25.

DOSH. (1996). Guidelines on occupational safety and health in the office. Putrajaya: Department of Occupational Safety and Health, Ministry of Human Resource Malaysia.

DOSH. (2005). Code of practice of indoor air quality. Putrajaya: Department of Occupational Safety and Health, Ministry of Human Resource Malaysia

DOSH. (2006). Annual report 2006. Putrajaya: Department of Occupational Safety and Health, Ministry of Human Resource Malaysia

Esquer J, N. Elenesb, A. Zavala. (2009) Pollution Prevention in an Auto Assembly Plant in Mexico. In. 2nd International Workshop | Advances in Cleaner Production. Key Elements For A Sustainable World: Energy, Water And Climate Change. São Paulo - Brazil - May 20th-22nd - 2009

Granadillos, N. G. (1998). A study on the assessment of heat stress among Filipino workers. Workshop on health and working conditions in South East Asia, Rangsit University, Thailand

Graveling, R. A., L. A. Morris, et al. (1998). Working in hot conditions in mining: A literature review. HSE Contract Reserach Report No. 10/1998. HSE, Institute of Occupational Medicine

Guo, S.C.L. Chan, L.Y. (2004). Indoor air quality in ice skating rinks in Hong Kong. Environ Res; 94: 327-35.

Harrison, P.T.C. (2002). Indoor air guidelines. OccupEnviron Med; 59: 73-4.

Jones, A.P. (2002). Indoor Air Quality. In. Air Pollution Science for the 21 ${ }^{\text {st }}$ Century. Edited by J. Austin, P. Brimblecombe and W. Sturges. Elsevier Science Ltd.

Kvarnström, S. (1997). Stress prevention for blue-collar workers in assembly-line production, 1-32, ILO, Geneva.

Maroni, M. Seifert, B. Lindvall, T. (1995). Indoor Air Quality - a Comprehensive Reference Book. Elsevier, Amsterdam.

NIOSH. (1986). Criteria for a recommended standard...Occupational exposure to hot environments: Revised criteria. Washington, D.C., National Institute for Occupational Safety and Health

NIOSH. (1993). In-depth survey report: control technology for autobody repair and painting shops at Team Chevrolet, Colorado Springs, Colorado. Cincinnati. US Department of Health and Human Services, Centers for Disease Control, National Institute for Occupational Safety and Health, DHHS-NIOSH.

OSHA. (1999). Heat stress: OSHA Technical Manual, U.S. Department of Labor. 
Prime Minister's Department. (2005). National automotive policy framework. Putrajaya: Prime Minister's Department.

Ramachandran, G. Adgate, J.L. Church, T.R. (2002). Indoor air quality in two urban elementary schools: comfort parameters and microbial concentrations in air and carpets. California: The 9th International Conference on Indoor Air Quality and Climate, 2002.

Ramphal, L. (2000). Heat stress in the workplace. BUMC PROCEEDINGS; 13:349-350

Ramsey, J. D. (1999). Limiting injury/illness at the hot workplace. Safety Science Monitor Retrieved 27 July, 2005, from http://www.monash.edu.au/muarc/ipso/vol3/oh1.pdf

Seltzer, J.M. (1997). Sources, concentrations, and assessment of indoor pollution. In: Bardana, E.J., Montanaro, A. (Eds.), Indoor Air Pollution and Health. Marcel Dekker, New York, pp. 11-60.

Simon, H.B. (1994) Hyperthermia and heatstroke. Hosp Pract. 29(8): p. 65-8, 73, 78-80.

TSI Inc. (2003a). Q-Trak Plus IAQ Monitor Model 8552/8554: Operation and service manual. Shoreview, MN: TSI Inc,

TSI Inc. (2003b). DUSTTRAK Aerosol Monitor: operation and service manual Model 8520. Shoreview, MN: TSC Inc,

Wildeboor, J. and J. Camp (1993). Heat stress: its effect and control. AAOHN J 41(6): 268-74 


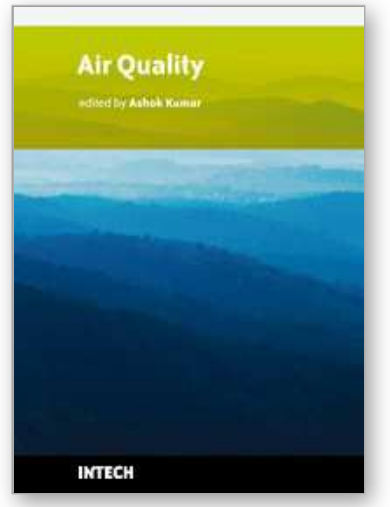

\author{
Air Quality \\ Edited by Ashok Kumar
}

ISBN 978-953-307-131-2

Hard cover, 382 pages

Publisher Sciyo

Published online 18, August, 2010

Published in print edition August, 2010

Air pollution is about five decades or so old field and continues to be a global concern. Therefore, the governments around the world are involved in managing air quality in their countries for the welfare of their citizens. The management of air pollution involves understanding air pollution sources, monitoring of contaminants, modeling air quality, performing laboratory experiments, the use of satellite images for quantifying air quality levels, indoor air pollution, and elimination of contaminants through control. Research activities are being performed on every aspect of air pollution throughout the world, in order to respond to public concerns. The book is grouped in five different sections. Some topics are more detailed than others. The readers should be aware that multi-authored books have difficulty maintaining consistency. A reader will find, however, that each chapter is intellectually stimulating. Our goal was to provide current information and present a reasonable analysis of air quality data compiled by knowledgeable professionals in the field of air pollution.

\title{
How to reference
}

In order to correctly reference this scholarly work, feel free to copy and paste the following:

Aziah Daud, Edimansyah Abdin, Azwan Aziz, Lin Naing and Rusli Nordin (2010). Assessment of Indoor Air Quality and Heat Stress Exposure in an Automotive Assembly Plant, Air Quality, Ashok Kumar (Ed.), ISBN: 978-953-307-131-2, InTech, Available from: http://www.intechopen.com/books/air-quality/assessment-ofindoor-air-quality-and-heat-stress-exposure-in-an-automotive-assembly-plant

\section{INTECH}

open science | open minds

\section{InTech Europe}

University Campus STeP Ri

Slavka Krautzeka 83/A

51000 Rijeka, Croatia

Phone: +385 (51) 770447

Fax: +385 (51) 686166

www.intechopen.com

\section{InTech China}

Unit 405, Office Block, Hotel Equatorial Shanghai

No.65, Yan An Road (West), Shanghai, 200040, China

中国上海市延安西路65号上海国际贵都大饭店办公楼405单元

Phone: +86-21-62489820

Fax: +86-21-62489821 
(C) 2010 The Author(s). Licensee IntechOpen. This chapter is distributed under the terms of the Creative Commons Attribution-NonCommercialShareAlike-3.0 License, which permits use, distribution and reproduction for non-commercial purposes, provided the original is properly cited and derivative works building on this content are distributed under the same license. 